\title{
WHITMAN AND LEBANON'S ADONIS
}

\author{
Roger Asselineau ANd Ed Folsom
}

THERE HAVE BEEN POETS from outside America who in the past have seriously questioned Whitman and challenged his beliefs about the United States and democracy-Pedro Mir of the Dominican Republic comes to mind ${ }^{1}$ - and now there is another, this time from the Near East. Adonis is the pen name of Ali Ahmed Said, who was born in a village near Latakia, Syria, in 1930. He obtained a degree in philosophy at the University of Damascus and moved to Lebanon in 1956, where he became a citizen. Later he studied and taught in Paris at the Sorbonne and then taught at Georgetown University in the United States and at the University of Geneva. The author of several collections of poems in Arabic, Adonis has translated into Arabic poems by T. S. Eliot and the complete poetical works of Saint-John Perse and has published an anthology of Arabic poetry. His poetry and criticism have been credited with "far-reaching influence on the development of Arab poetry," including the creation of "a new poetic language and rhythms, deeply rooted in classical poetry but employed to convey the predicament and responses of contemporary Arab society." According to Mirene Ghossein, "one of the main contributions of Adonis to contemporary Arabic poetry is liberty - a liberty with themes, a liberty with words themselves through the uniqueness of poetic vision." Selections of his work have been translated into English, Spanish, French, German, and other languages. One of those works, translated into French as Tombeau de New York and into English as The Funeral of New York ${ }^{4}$ is a violently anti-American long poem in which Whitman, as the champion of democracy, is taken to task, particularly in Section 9, which addresses Whitman directly.

Adonis's namesake, of course, was that handsome Syrian adolescent with whom Venus fell in love, but she had to share him with Proserpine so that his life was equally divided between Olympus and Pluto's realm. One suspects that the present Adonis's life is similarly divided between light and darkness, between the East and the West. He acknowledges that he "carries Cuba on his shoulders and, when in New York, asks: 'Castro, when will he come?' and [he] waits between Cairo and Damas half way on the road to be taken." Adonis has written that "the unity of the 'self' is only apparent, for this self is fundamentally a 
rift," since "the 'other' lives deep inside the 'self"" and thus "there is no 'self' without the "other." "Living identity," he says, "exists within the fertile, ambiguous relational tension between the self and the other." 5 In his complex negotiations between Europe, America, and the Arab world, Adonis clearly has developed an identity that embodies those "relational tensions."

Adonis experienced such a fertile, ambiguous, and divided self when he was in New York during the Vietnam War in the early 1970s. At that time, he asked himself "What is New York?" The Funeral of New York is his answer:

New York is a woman

holding, according to history,

a rag called liberty with one hand

and strangling the earth with the other.

New York

is damp asphalt

with a surface like a closed window. (57)

The poet looks to Whitman for help in opening the window, in figuring out what this "city on four legs / heading for murder" really means: "I said: 'Whitman can open it.' / I say his password now, / but the absent god hears nothing." As has been the case for many twentieth-century poets who talk back to Whitman, modern-day New York seems to Adonis a hopelessly degraded version of the city Whitman so passionately sang about, a city now devoid of Whitman's inspiriting presence. Brooklyn Bridge today "bridges Whitman and Wall Street, / a link between leaves of grass and the paper leaves / of dollar bills" (57), and the city seems only the effluvium of a decaying culture: "Out of an empire state of dirt and garbage / rises the stink of history" (58). The poem rails against American involvement in Vietnam: "I wake up in the morning, shouting, 'Nixon, how many children have you killed today?"' (70).

Adonis assumes the role of prophet- "One needs courage to ask the prophet's questions" (67) —and his poem is filled with moments of prophetic insight:

Shall I prophesy that heads, not eyes, are blind,

That tongues, not words, are sterile?

New York is Wall Street and streets

named after numbers.

Call it Medusa,

a market for slaves

where people grow as plants grow

in glass gardens. ... (58)

The dark prophecies proliferate: "An eastern wind uproots tents and skyscrapers / with its wings" (60); "A battle between grass [Whitman's 
grass as the symbol of life] and computers is coming. / The whole century is hemorrhaging" (63); "Harlem . . . Your people disappear like bread into a mouth. / But you shall erase New York. / You shall take it by storm / and blow it like a leaf away" (65); "The world needs a deluge,' / I said and wept instead of rage[d]" (67). The narrator is stuck between an Arab world that seems to have dropped out of history ("the Arab map ... resembled a mare shuffling on, dragging its history like saddlebags"; "names in Arabic . . . lagging like a wayward planet without a past / and slowing to a stop") and a Western world that seems to be on the manic edge of the end of history ("New York is a hole in the world's pouch / for madness to gush in torrents" [65]). He is a double exile, a fragmented self, stranded from his native past in an empty and foreign present that points toward a dead future. As horrific as New York is, though, it is still his present reality, furnishing the material of his poetry:

In spite of this New York is not nonsense.

After all, it is two words.

But when I write the letters of Damascus,

I mimic nonsense.

I create nothing.

Damascus-a sound, something of the wind.

Years back, she stepped out of my pages

and has not returned. (68)

In despair at what he finds in "New York-the General Motors of Death," Adonis imagines himself getting up before dawn and awakening Whitman, who becomes the subject of Section 9:

\footnotetext{
Walt Whitman,

I see letters careening toward you down the streets of Manhattan.

Each letter carries cats and dogs.

To cats and dogs the twenty-first century!

To people, extermination in this

the American century. (70)
}

At first Whitman is hard to find: "Whitman, I did not see you in all Manhattan" (70), but then Adonis takes up a line from "Song of Myself"- "The clock indicates the moment" - and hears Whitman's words as a suggestion of a revolutionary moment, a moment of historic change that could join the American bard and the Arab poet in an alliance that has the potential to overthrow the unfeeling capitalist and imperialist power that the United States has become: 
Whitman,

a clock announces time to New York

like garbage thrown to a woman

who is nine parts ashes.

A clock announces time

where Pavlov experiments with people

in the system of New York.

A clock announces time

while a letter comes from the east

written in a child's blood.

I scan it until the child's doll

becomes a cannon or a rifle.

Corpses in their streets make sisters

of Hanoi, Jerusalem and Cairo.

He repeats the quotation from "Song of Myself" once again and this time adds "I see what you never saw / and know what you could never know" (71). Adonis does not hold Whitman responsible for the current state of affairs; he instead tries to inform him of what has become of his beloved America. In this demonic New York, Whitman himself is now an exile: "And you, Walt Whitman, / stay exiled like an immigrant. / Have you become a bird unknown in the American sky?" (71). So Adonis, awakening Whitman to the present, now seeks to join his vision to that of the American poet: "Whitman, / let our turn be now. / Let's make a ladder with our visions, / weave a common pillow with our footsteps. / Shall we be patient? / Man dies but still outlasts his monuments. / Let our turn be now" (71-72). Adonis imagines himself and Whitman writing a new book of prophecy, "a prophecy that grows and grows, / a beginning of a wise madness" (72), that will undo contemporary America and join the world's oppositions, allowing the dispossessed to repossess the earth, to "capture a plain and sparkling country / from the birds": "I expect the Volga to flow between Manhattan and Queens / I expect the Huang Ho to replace the Hudson." In his vision, Adonis recruits Whitman to help carry out the destruction of war- and death-obsessed American culture, a destruction that will result in new light and life:

Let our turn be now.

Let us be the executioners.

Let time keep floating on the sea of that equation:

New York plus New York equal a funeral.

New York minus New York equal the sun.

The poem ends with the poet leaving New York and returning to Beirut - "Beirut, / I still salute you" - where his "writings become a palm tree; / the tree, a dove" (74). Like Whitman, Adonis wants to sing "the open road" and hopes "to make a more vigorous thrust towards a horizon open on the infinite," but he distrusts and rejects the Western cul- 
ture of consumption, and, despite his sympathy and even affection for Whitman, he buries him under the wreckage of modern-day New York.

University of Paris-Sorbonne

The University of Iowa

\section{NOTES}

1. See Pedro Mir, Contracanto a Walt Whitman (Guatemala: Ediciones Saker-Ti, 1952).

2. Abdullah al-Udhari, trans., Victims of a Map [bilingual selection of poems by Mahmud Darwish, Samih al-Qasim, and Adonis] (London: Al Saqi, 1984), 87.

3. Mirene Ghossein, "Introduction," in Adonis, The Blood of Adonis, translated from the Arabic by Samuel Hazo (Pittsburgh: University of Pittsburgh Press, 1971), xviii.

4. Adonis, Tombeau pour New York, translated from the Arabic by Anne Wade Minkowski (Paris: Sindbad, 1986); Adonis, The Funeral of New York, in The Pages of Day and Night, translated from the Arabic by Samuel Hazo (Marlboro, Vermont: Marlboro Press, 1994), 57-74.

5. "Poetry and Apoetical Culture," in Pages of Day and Night, 107.

6. Adonis, Introduction à la poétique arabe, translated from Arabic by Bassam Tahlan and Anne Wade Minkowski; foreword by Yves Bonnefoy (Paris: Sindbad, 1985), 115116. 